\title{
Perancangan Aplikasi Penjualan Berbasis Android Sebagai Media Pemesanan Pada Distro Online
}

\author{
Eni Pudjiarti ${ }^{1}{ }^{\star}$, Siti Faizah ${ }^{1}$ \\ 1 Teknik Informatika; Universitas Nusa Mandiri; Jl. Jatiwaringin Raya No. 02 Cipinang Melayu \\ Jakarta Timur, 13620, Jakarta, Indonesia; e-mail: eni.epr@nusamandiri.ac.id, \\ siti.sfz@nusamandiri.ac.id \\ * Korespondensi: e-mail: eni.epr@nusamandiri.ac.id
}

Diterima: 28 Oktober 2021; Review: 30 Nopember 2021; Disetujui: 01 Desember 2021

Cara sitasi: Pudjiarti E, Faizah S. 2021. Perancangan Aplikasi Penjualan Berbasis Android Sebagai Media Pemesanan Pada Distro Online. Bina Insani ICT Journal. Vol. 8 (2): 176-186.

\begin{abstract}
Abstrak: Di zaman sekarang ini perusahaan dan bisnis startup berkembang sangat cepat seiring dengan perkembangan zaman, dan dengan perkembangan zaman itu juga, itu hampir setiap masyarakat di era sekarang memiliki perangkat handphone dan sudah dianggap salah satu bagian yang paling penting dalam menjalani kehidupan sehari-hari. Dan sekarang ada banyak jugajenis perusahaan atau bisnis startup yang dapat kita temui, dan salah satu yang paling sering ditemui merupakan jenis startup yang ditargetkan untuk masyarakat pengguna handphone, dan dalam pemasarannya perusahaan dan bisnis startup ini membuat suatumedia untuk memudahkan masyarakat dalam mengakses konten yang mereka jual, yaitu dalam bentuk suatu aplikasi berbasis sistem android. Ditambah lagi dengan adanya wabah Covid-19 dan juga kebijakan-kebijakan pemerintah yang membatasi pergerakan masyarakat, aplikasi startup ini sangat membantu dapat menjadi solusi bagi para pengusaha untuk memenuhi penjualan mereka ditengah masa pandemi, serta menyebarluaskan aplikasi Distro supaya lebih dikenal luas oleh masyarakat sehingga berminat untuk menggunakan aplikasi Distro. Beberapa perusahaan dan bisnis kecil yang masih berkembang atau biasa disebut usaha mikro ini sudah mulai mencoba cara- cara baru dalam memasarkan apa yang mereka jual dalam pandemi yang masih terjadi saat ini dan salah satunya membuat aplikasi berbasis sistem android. selain memudahkan penjual memasarkan yang mereka jual, masyarakat yang berperan sebagai pembeli pun dapat dengan mudah mengakses informasi dan melakukan transaksi jual-beli melalui aplikasi tersebut tanpa harus datang ke toko fisik secara langsung. Dan dengan dibuatnya aplikasi ini diharapkan dapat menjadi sebagai contoh untuk bagaiman usaha mikro dalam membuat aplikasi untuk bisnis yang mereka jalani. Berdasarkan uraian di atas, penulis mencoba membuat sebuah rancangan Aplikasi Distro Online Berbasis Android dan sistem Aplikasi Android ini dikembangkan dengan menggunakan metode pengembangan Waterfall, dengan bahasa pemrograman java dan database yang digunakan adalah $\mathrm{cPanel}$.
\end{abstract}

Kata kunci: android, aplikasi, startup, usaha mikro

Abstract: Startup companies and businesses are growing very quickly along with the times, andwith the development of this era, almost every society in this era has a mobile phone and is considered one of the most important parts of everyday life. And now there's all types of startup companies or businesses that we can find, and one of the most frequently encountered is the type of startup that is targeted at the mobile phone users, and to market what these startup companies and businesses sell, a media platform is created to make it easier for people to access the content that they are provided, namelyby forming an app based on the android system. Coupled with the COVID-19 outbreak and also government policies that restrict people's movement, This startup application is very helpful, it can be a solution for entrepreneurs to meet their sales in the midst of a pandemic, as well as disseminate the Distro application so that it is more widely known by the public so that they are interested in using the Distro application. 
Some companies and small businesses that are still in development or commonly called microenterprises have started tryingnew ways to market what they provided in the current pandemic and one of them is bymaking applications based on the Android system. In addition to making it easier for sellers to market what they sell, customers can easily access information and made transactions through the application without having to come to a the store directly. And with the creation of this application, it is hoped that it can serve as an example for howmicro-enterprises make applications for the businesses they do. Based on the description above, the author tried to create a design of the Android-Based Online Distro Application and the Android Application system was developed using waterfall development methods, with the java programming language and database used is cPanel.

\section{Keywords: android, application, micro business, startup}

\section{Pendahuluan}

Bisnis startup atau perusahaan startup secara umum dikenal sebagai bisnis atau perusahaan yang belum lama didirikan atau baru saja merintis. Dalam referensi [1] startup didefinisikan sebagai perusahaan dibidang industri digital yang telah memilikibadan usaha atau memiliki produk digital yang sudah dirilis ke pasar. Istilah startup sendiri mulai dikenal pada masa buble dot-com, yaitu ketika pada tahun 1998-2000 banyak perusahaan yang sedang gencar-gencarnya membuka website pribadi. Dengan seiring berjalannya waktu internet dan teknologi semakin berkembang, dan semakin banyak juga yang melihat internet sebagai peluang bisnis. Dengan ditambah berbagai ide-ide kreatif dari generasi milenial, mereka mencoba untuk menciptakan suatu peluang bisnis baru yang menghasilkan produk atau sesuatu yang bermanfaat, dan darisitu startup mulai berkembang hingga kini. Pada masa kini startup memiliki berbagai jenis di berbagai bidang, seperti di bidang games, properti, asuransi, sekuritas dan perdagangan.

Namun sejak memasuki tahun 2020, dunia mulai digemparkan oleh sebuah wabah virus yang tersebar hampir di seluruh dunia, yaitu adalah virus COVID-19 atau yang sering disebut dengan virus corona. Selain dalam bidang kesehatan, virus ini jugaberdampak besar ke berbagai bidang lain, termasuk perusahaan startup besar dan kecil atau yang sering disebut usaha mikro. Dikutip dari [2] Indonesia menjadi salah satu negara yang terkena dampak besar di berbagai bidang akibat virus ini, mulai dari bidang pendidikan baik pendidikan dasar, menengah dan tinggi, perhotelan, pariwisata, farmasi dan produk kesehatan, angkutan online, dan perdagangan. masih dalam kutipan [3] disebutkan dalam bidang perdagangan memiliki tiga sisi yang terkena dampak akibat virus corona ini, yaitu bagi pelaku usaha (termasuk usaha mikro dan kecil), konsumen, dan pemilik tempat usaha. Banyak usaha mikro dan kecil yang terpaksa menutup usaha mereka sementara atau bahkan selamanya akibat konsekuensi dari himbauan penutupan pusat perbelanjaan dan social distance yang diberlakukan oleh pemerintah, contohnya seperti tidak memenuhi standar kesehatan dari pemerintah dan kerugian akibat berkurangnya konsumen. Karena usaha ini masih sebatas usaha mikro banyak dari jenis usaha ini yang berdagang hanya mengandalkan kepada konsumen yang datang langsung ke toko. Akan tetapi semenjak diberlakukannya penutupan berbagai pusat perbelanjaan dan toko-toko serta social distance berskala nasional sebagai bentuk pencegahan dari penularan virus corona ini, banyak dari konsumen yang tidak lagi dapat keluar langsung untuk membeli kebutuhan mereka dan yang akhirnya mereka akan berlaih dengan memenuhi kebutuhan mereka melalui usaha-usaha besar yang diizinkan tetap buka setelah memenuhi validasi standar kesehatan dari pemerintah. Dari usaha-usaha besar ini menyediakan sarana untuk keterbatasan konsumen dalam memenuhi kebutuhan mereka, seperti menyediakan toko online yang mana konsumen dapat berbelanja online dari rumah atau dimana saja dan kapan saja mereka membutuhkannya. Pembayaran akan diterima penjual apabila barang telah sampai kepada konsumen atau bisa juga berupa Cash on Delivery (CoD) dimana konsumen dapat membayar langsung kepada kurir apabila barang terlah diantarkan, sehingga konsumen tidak perlu lagi ragu akan tertipu dengan metode belanja online ini. Toko online turut serta menawarkan berbagai diskon secara online, dan terbukti toko-toko online ini memiliki banyak peminat terutama di tengah era pandemi saat.

Bahasan mengenai toko online di atas kebanyakan hanya berlaku kepada usaha-usaha menengah ke atas yang memang menyediakan sarana tersebut serta konsumen kalangan atas karena toko online ini memiliki harga yang jauh di atas rata-rata dari usaha-usaha mikro untuk 
masyarakat umum [4]. dan untuk usaha mikro sendiri banyak tidak mengerti bahkan mengetahui tentang metode toko online ini sehingga terpaksa mengakhiri usaha mereka. Berdasarkan latar belakang yang telah diuraikan, adapun permasalahan yang dihadapi diantaranya bagaimana membantu pengusaha mikro yang terpaksa menutup usaha mereka karena masa pandemi. Dari permasalahan yang ada, penulis telah menyediakan solusinya yaitu merancang suatu aplikasi yang diharapkan dapat menjadi solusi bagi para pengusaha dan masyarakat umum untuk memenuhi kebutuhan pokok mereka ditengah masa pandemi seperti ini. Adapun solusi yang disediakan yaitu merancang Aplikasi Distro Online Berbasis Android. Cara kerja dari aplikasi distro yang diberikan oleh penulis yaitu dengan dengan menjelaskan cara kerja dan proses dari aplikasi tersebut dengan harapan nantinya aplikasi ini dapat meringankan permasalahan yang dihadapi oleh para pengusaha.

Aplikasi dalam bahasa Indonesia berarti pengolah, berasal dari kata application yang artinya bentuk benda dari kata kerja to apply. Dikutip dari [5] Aplikasi merupakan software yang dibuat oleh suatu perusahaan komputer untuk mengerjakan tugas-tugas tertentu, contohnya seperti Microsoft Word dan Microsoft Excel. Dalam bahasa komputer Program adalah suatu rangkaian instruksi-instruksi yang dimuat secara logis dan sistematis dengan perpaduan bahasa pemograman yang dapat dimengerti oleh komputer dan akan di eksekusi sesuai program yang diperintahkan.

\section{Metode Penelitian}

Untuk memenuhi kebutuhan data yang dibutuhkan maka peneliti melakukan pengumpulan data yang diperlukan dengan menggunakan metode pengumpulan data [6]. Pertama, Metode Observasi yaitu Teknik pengumpulan data dengan mengadakan penelitian dan pengamatan secara online dengan mencari jurnal-jurnal yang dibutuhkan karena keterbatasan yang dialami untuk memenuhi kebutuhan mereka selama masa pandemi. Kedua, Metode Wawancara Peneliti mengadakan sesi tanya jawab melalui google form online mengenai apa saja kebutuhan yang mereka perlukan dan kendala yang dialami untuk memenuhi kebutuhan tersebut. Form ini akan di kirimkan kepada 20 orang. Ketiga, metode Studi Pustaka Yaitu pengumpulan data dengan cara mencari dan mengumpulkan serta mempelajari sumbersumber data dari jurnal, paper, buku, dan bacaan-bacaan yangterkait dengan judul penelitian.

Metode pengembangan yang digunakan penulis dalam penyusuan skripsi ini adalah dengan menggunakan Model Sekuensial Linier atau Waterfall Development Model [6]. Pada gambar 1 dijelaskan metode pengembangan langkah pertama yang dilakukan dengan menganalisa kebutuhan untuk mengetahui kebutuhan apa saja yang dibutuhkan oleh pengguna. Kedua Desain system untuk membuat perangkat lunak yang terdiri dari: struktur data, arsitektur perangkat lunak, User Interface dan Pengkodean. Ketiga Penulisan kode pemrograman sehingga aplikasi dapat berjalan dengan baik, Keempat Pengujian program untuk mengurangi kesalahan yang terjadi ketika aplikasi dijalankan dan menguji kualitas dari aplikasi yang dibuat. Kelima Penerapan Program dengan memberikan pelatihan kepada pengguna cara menjalankan aplikasi.

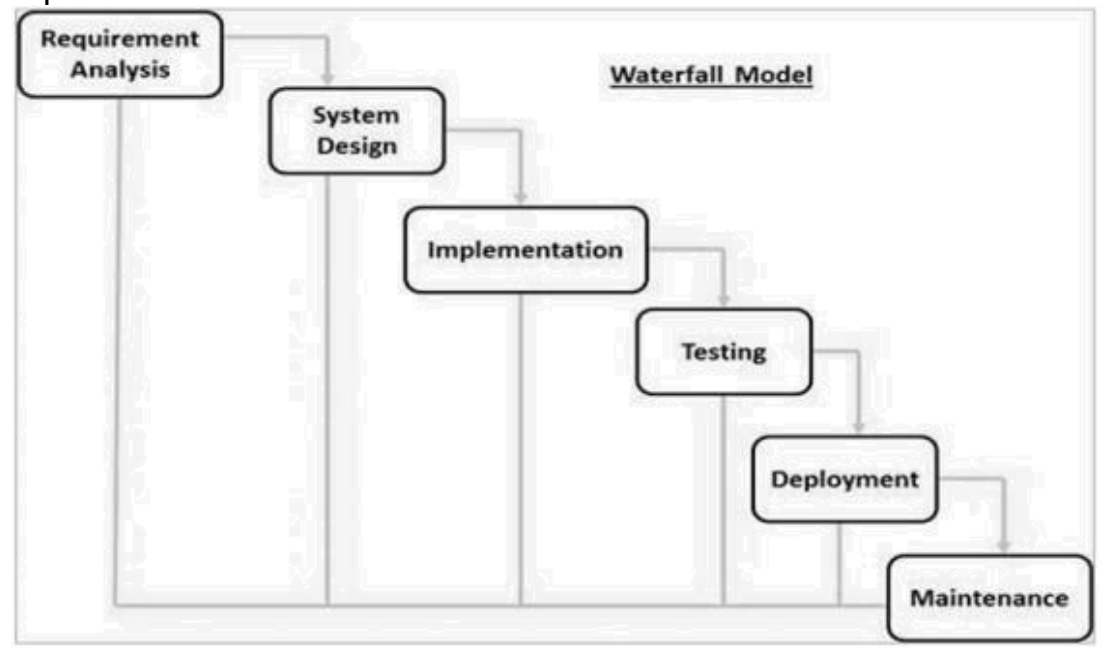

Sumber: T.S. Jaya [2018]

Gambar 1. Metode Pengembangan Aplikasi. 
yaitu:

Dalam pengembangannya metode waterfall memiliki beberapa tahapan yang runtut [8],

\section{Rekayasa Sistem (System Engineering)}

Tahapan pertama dimulai dengan pengumpulan data yaitu dengan cara menggunakan teknik penelitian. Teknik pengumpulan data yang digunakan yaitu melakukan sesi tanya jawab dengan menggunakan google form online, google form ini dikirimkan kepada 15 orang yang seumuran dengan penulis. Setelah terkumpul semua data yang diperlukan maka data akan diproses [9].

\section{Perangkat Lunak Syarat Analisis (Software Requirements Analysis)}

Tahap sistem selanjutnya yaitu melakukan tahap analisis terhadap kebutuhan konsumen melalui Customer Analysis, selain itu dilakukan juga analisis terhadap model bisnis menggunakan Business Model Canvas [10]. Di tahap ini penulis melakukan analisa pada sistem berjalan, sistem belum bisa melakukan transaksi pemesanan dan pembelian secara online merupakan permasalahan yang ditemukan pada perusahaan tersebut, Sistem ini tidak memudahkan customer dalam melakukan transaksi dan dinilai sangat tidak efisien [11]. Sebuah sistem tidak dapat berjalan dengan sendirinya, dibutuhkan support sistem yang bagus untuk mengembangkannya [12] agar produk yang diciptakan bisa terpasarkan dengan baik.

\section{Perancangan (Design)}

Perumusan masalah yang telah diuraikan, penulis membuat dan merancang aplikasi dengan menggunakan software yang baik untuk memenuhi kebutuhan [13]. Sebelum menghubungkan ke suatu sistem navigasi dibutuhkan perancangan awal dimana perancangan tersebut akan menghasilkan tampilan program yang baik. a. Unified Modelling Language (UML) yang berisikan skema dari urutan kegiatan yang dilakukan oleh pengguna dengan aplikasi yang digunakan. Unified Modelling Language (UML) merancang model sebuah sistem dimana sistem tersebut menjelaskan mengenai cara kerja dari aplikasi yang dibuat [14]. b. Entity Relationship Diagram (ERD) merupakan suatu database yang menyimpan atribut dari aplikasi yang dibuat, dimana atribut yang dibuat disesuaikan dengan kebutuhan dari aplikasi seperti atribut untuk pemesanan dan pembelian barang [15]. c. Sebagian besar state Activity Diagram yaitu menggambarkan alur sistem dari aplikasi yang dibuat dari pembeli yang ingin melihat dan memilih produk yang ingin dipesan sampai dengan pembeli tersebut melakukan pemesanan barang [16]. $d$. Tahapan selanjutnya yaitu implementasi program, untuk pembuatan aplikasi ini dibutuhkan beberapa perangkat pendukung yang harus sesuai standar kebutuhan dan apabila tidak sesuai standar kebutuhan, akan mengakibatkan aplikasi tidak berjalan seperti seharusnya, dan perangkat tersebut terbagi dalam perangkat keras dan perangkat lunak, dimana-mana masing-masing perangkat tersebut memiliki peran tersendiri dalam menunjang pembuatan aplikasi [17]. Perangkat pendukung yang dibutuhkan yaitu laptop dan handphone. e. Deployment Diagram menunjukkan bagian-bagian software yang digunakan [18] antara lain Android Studio untuk menyusun aplikasi, bahasa pemrograman yang digunakan yaitu java, cPanel digunakan sebagai database, untuk mendesain tampilan-tampilan dari aplikasi menggunakan CorelDraw, kemudian Vysor digunakan untuk menghubungkan laptop dengan handphone pada proses uji coba aplikasi, microsoft Visio untuk merancang workflow dari aplikasi, dan VirtualBox digunakan untuk menciptakan virtual operating system yang dibutuhkan saat pembuatan aplikasi.

\section{Pengkodean (Coding)}

Pada tahap pengkodean ini penulis menggunakan bahasa pemrograman dimana pemrograman tersebut bisa dijalankan diberbagai macam jenis komputer atau perangkat termaksud handphone. Untuk mensupport perangkat di sebuah handphone dibutuhkan sebuah 
IDE yang bisa digunakan untuk pengembangan aplikasi android [19]. Adapun perangkat yang dimaksud yaitu penulis mengaplikasikan bahasa pemrograman java untuk menerapkan pemrograman yang tersusun dan dibantu dengan perangkat Android Studio untuk menyusun aplikasi pada sistem perancangan aplikasi ini [20].

\section{Uji Coba (Testing)}

Tahap selanjutnya yaitu masuk ke tahap uji coba atau testing dengan menggunakan blackbox testing, Testing tersebut mengarah ke tahap pengujian yang berfokus pada fungsi perangkat lunak dan cara mengoperasikannya, apakah interface sudah bisa berjalan dengan sempurna [21]. Blackbox testing dilakukan dengan menggunakan skenario pengujian sistem, test case sistem, hasil yang diharapkan dari sistem yang dibuat, kemudian hasil pengujiannya apakah sudah sesuai harapan [22].

\section{Pemeliharaan (Maintenance)}

Setiap pembuatan aplikasi diperlukan pemeliharaan sistem atau maintenance. Untuk maintenance harus dilakukan secara rutin. Dengan adanya pemeliharaan sistem mampu memperbaiki kesalahan dalam sistem ataupun dalam jaringan yang terhubung. Untuk pemeliharaan sistem, terdapat suatu kombinasi yang harus diperhatikan dengan baik. Tindakan yang dilakukan pada tahap ini adalah jika terjadi kesalahan dalam sistem, operator (user) harus dapat memaintenance sistem dan juga membackup data agar sistem berjalan dengan baik [23].

\section{Hasil dan Pembahasan Analisa Kebutuhan}

Analisa kebutuhan aplikasi meliputi: 1) Pengguna dapat mengakses aplikasi, 2) Pengguna dapat memilih produk yang diinginkan, 3) Pengguna dapat memesan dan membeli produk, 4) Pengguna dapat melakukan pembayaran untuk produk yang telah mereka beli, dan 5) Pengguna dapat menerima produk yang telah mereka beli.

\section{Rancangan User Interface}

Berisi tampilan-tampilan visual sebuah produk yang menjembatani sistem dengan pengguna dari aplikasi yang dapat dilihat dan digunakan secara langsung. Pada rancangan user interface memperlihatkan tampilan MockUp dari aplikasi yang sedang dirancang yang berupa design beberapa aspek mulai dari layout menu utama, logo, pemilihan warna dan penulisan yang mudah dibaca serta mempercantik tampilan.

\section{Rancangan Database}

Rancangan database berisi Entity Relationship Diagram (ERD) dan Logical Record Structure (LRS) yang telah dibuat [24]. Pada gambar 2 dijelaskan beberapa table yang saling berhubungan dengan field-field yang akan digunakan untuk membuat aplikasi penjualan.

Entitas admin memiliki atribut id_admin, nm_admin, alamat, no_hp. Entitas produk memiliki atribut kd_produk, nm_produk, merek, jenis, stok, harga. Entitas produsen memiliki atribut id_produsen, nm_produsen, alamat, no_hp. Entitas pesanan memiliki atribut $\mathrm{kd} \_p e s a n a n$, tgl_pesanan, $\mathrm{nm} \_$pesanan, id_pembelim kd_produk, nm_produk, harga, jumlah, total, status_pembayaran. Entitas detail pesanan memiliki atribut id_detail_pesanan, kd_pesanan, nm_produk, jumlahm berat_detail. Entitas komentar memiliki atribut id_admin, id_pembeli, kd_pembeli, komentar. Entitas pembeli memiliki atribut id_pembeli, nm_pembeli, alamat, no_hp, email, kode_pos. Entitas konfirmasi pembayaran memiliki kd_konfirmasi pembayaran, kd_pesanan, nm_pesanan, total, tgl_pembayaran. Entitas pengiriman memilki atribut kd_pengiriman, kd_pesanan, pengirim, penerima, jasa_pengiriman, tarif, ongkir, resi.

Kardinalitas relasi dalam ERD dijelaskan sebagai berikut: 1 admin mengelola $\mathrm{N}$ produk, $\mathrm{N}$ produsen mengupload $\mathrm{n}$ produk, 1 pembeli melihat $\mathrm{N}$ produk, 1 pesanan memiliki $\mathrm{N}$ detail pesanan, $\mathrm{N}$ pembeli memperoleh $\mathrm{N}$ konfirmasi pembayaran, $\mathrm{N}$ pembeli memperoleh $\mathrm{N}$ pengiriman. 


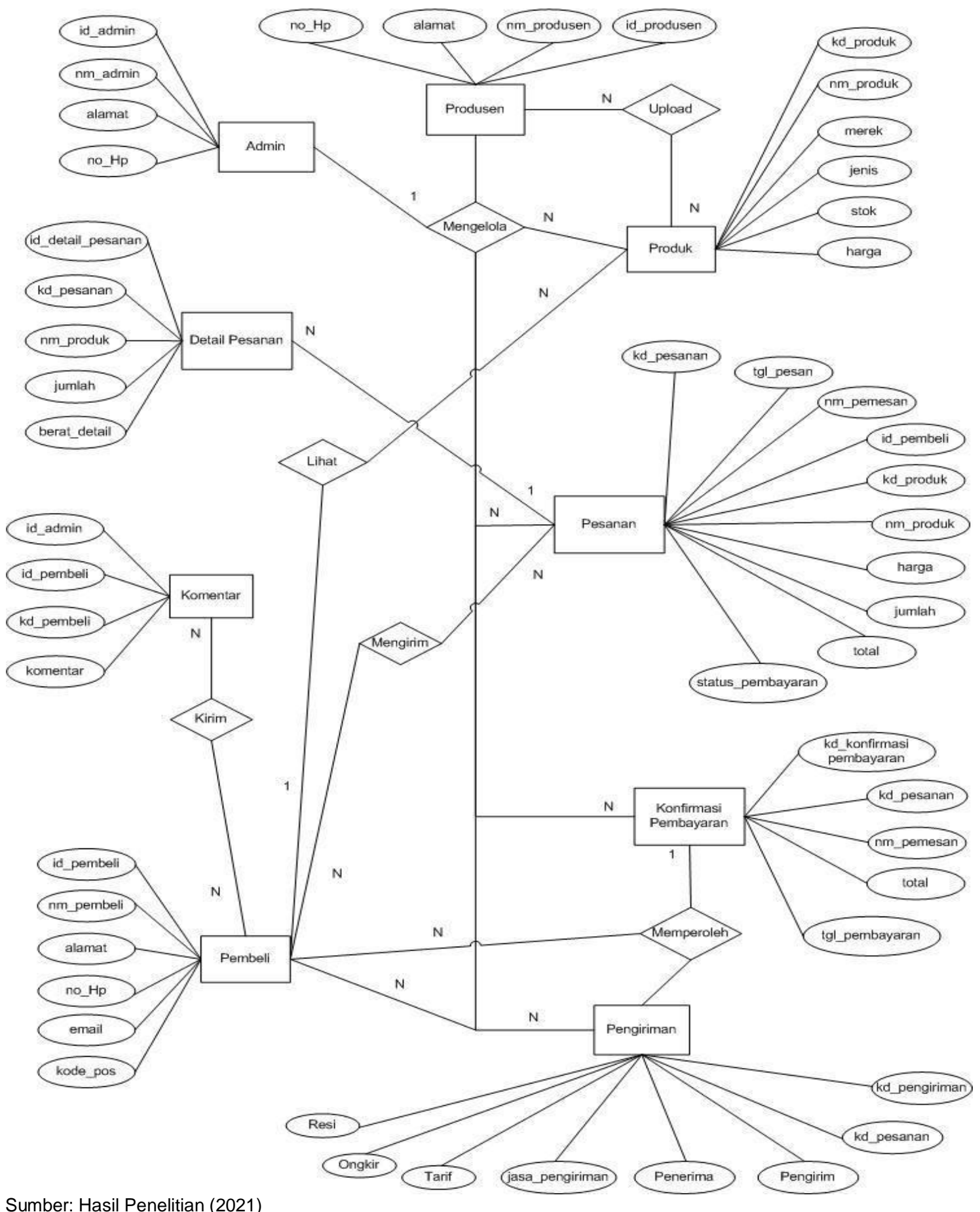

Sumber: Hasil Penelitian (2021)

Gambar 2. Entity Relationship Diagram (ERD)

Pada gambar 3. Logical Record Structure (LRS) merupakan suatu langkah untuk membentuk data-data dari diagram hubungan entitas yang ada di Entity Relationship Diagram (ERD) ke suatu LRS. Tabel admin memiliki nama field: id_admin sebagai primary key. Tabel produsen memiliki nama field: id_produsen sebagai primary key. Tabel produk memiliki nama field: kd_produk sebagai primary key. Tabel pembeli memiliki nama field: id_pembeli sebagai primary key. Tabel keranjang memiliki nama field: id_keranjang sebagai primary key dan kd_produk sebagai foreign key. Tabel pesanan memiliki nama field: kd_pesanan sebagai primary key dan id_pembeli dan kd_produk sebagai foreign key.Tabel konfirmasi pembayaran memiliki nama field: id_konfirmasi_pembayaran sebagai primary key dan kd_pesanan sebagai 
foreign key. Tabel pengiriman memiliki nama field: kd_pengiriman sebagai primary key dan kd_pesanan sebagai foreign key. Tabel detail pesanan memiliki nama field: id_detail_pesanan sebagai foreign key. Tabel komentar memiliki nama field: id_admin, id_pembeli dan kd_pembeli sebagai foreign key.

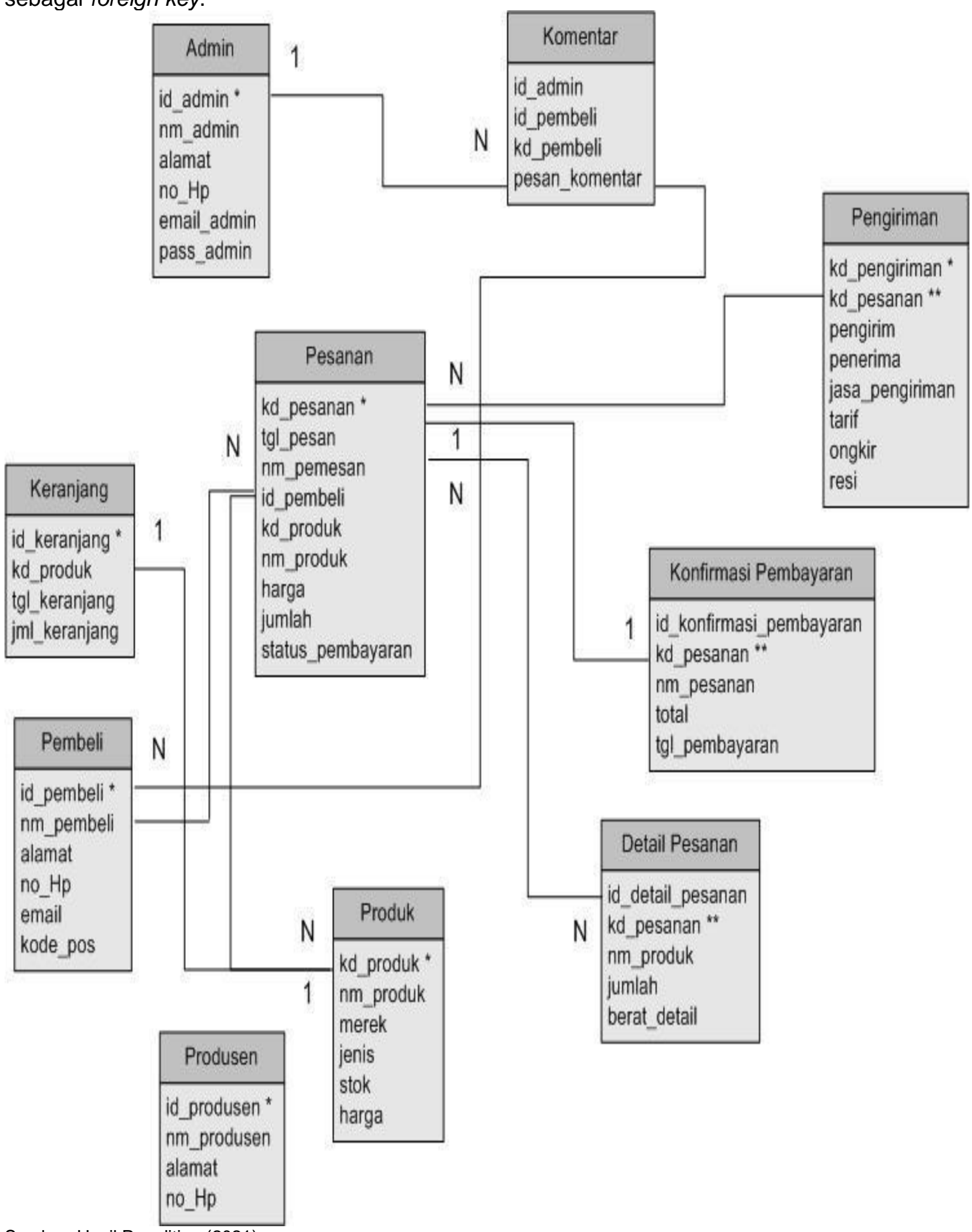

Sumber: Hasil Penelitian (2021)

Gambar 3. Logical Record Structure (LRS)

\section{Implementasi}

Pada gambar 4 memperlihatkan tampilan halaman utama dari aplikasi yang dapat digunakan secara langsung oleh pengguna. Terdiri dari kolom pencarian, logo, nama merk, kategori barang yang akan dilihat oleh pengguna dijelaskan pada gambar 4 . 


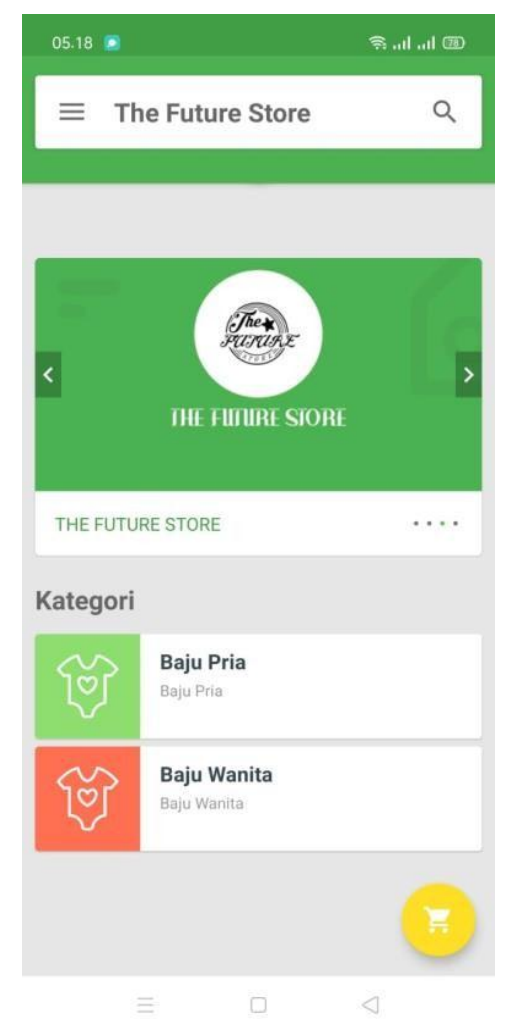

Sumber: Hasil Penelitian (2021)

Gambar 4. MockUp 2.0 Tampilan Halaman Utama

\section{Hasil Implementasi}

Berisi tampilan-tampilan dari aplikasi yang dapat dilihat dan digunakan secara langsung oleh pengguna. Berikut adalah MockUp dari aplikasi yang sedang dirancang terdiri dari Tampilan awal saat pengguna memilih aplikasi, lalu selanjutnya tampil menu utama yang terdiri dari kolom pencarian, highlight produk, kategori, Jika kategori dipilih maka akan tampil produk yang sesuai dengan kategori pilihan pengguna. Selanjutnya jika pengguna ingin menambahkan produk, prngguna bisa mengklik tombol tambahkan ke keranjang dan tampilan akan menuju ke keranjang belanja yang dijelaskan pada gambar 5 .

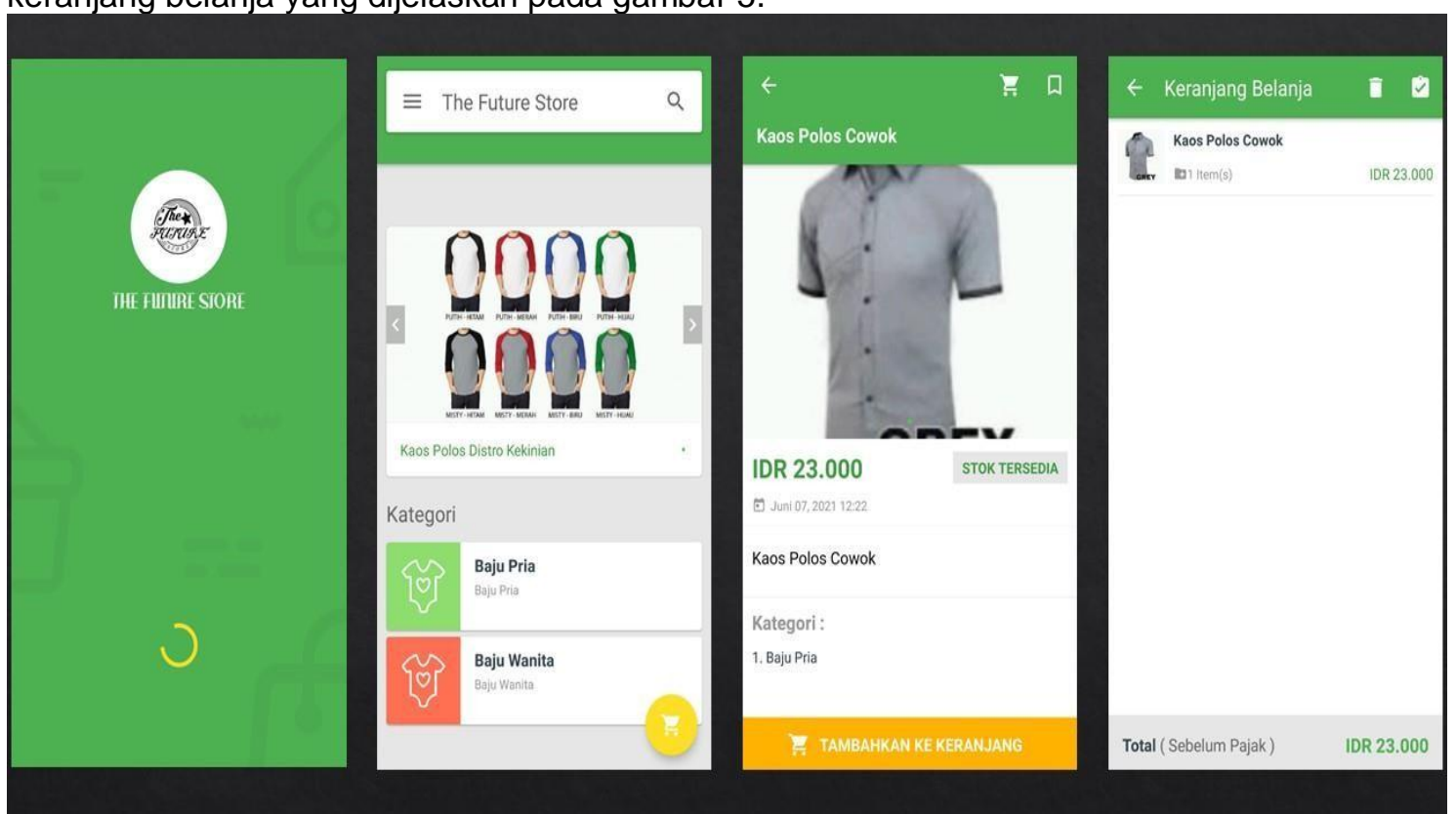

Sumber: Hasil Penelitian (2021)

Gambar 5. MockUp 2.0 Tampilan Halaman Utama 


\section{Pengujian Aplikasi}

Pengujian Aplikasi yang dilakukan pada unit aplikasi yang telah dibuat menggunakan metode pengujian black box [16].

Tabel 1. Hasil Pengujian Black Box Testing

\begin{tabular}{|c|c|c|c|c|c|}
\hline No & Skenario Pengujian & Test Case & $\begin{array}{l}\text { Hasil yang } \\
\text { diharapkan }\end{array}$ & $\begin{array}{l}\text { Hasil } \\
\text { Pengujian }\end{array}$ & Kesimpulan \\
\hline 1 & $\begin{array}{l}\text { Mengisi semua isian } \\
\text { data pada checkout, dan } \\
\text { langsung mengklik } \\
\text { "Checkout" }\end{array}$ & $\begin{array}{l}\text { Nama : Leopard Email : } \\
\mathrm{k}^{\star \star \star \star} @ \text { gmail.com } \\
\mathrm{HP}: 08138039^{* \star \star \star} \\
\text { Alamat : Jl. KP JawaPilih } \\
\text { Pengiriman : COD } \\
\text { Tanggal Pengiriman: } 2 \\
\text { Agustus 2021 } \\
\end{array}$ & $\begin{array}{l}\text { Sistem menerima data } \\
\text { yang diberikan dan } \\
\text { langsung memproses } \\
\text { data tersebut }\end{array}$ & $\begin{array}{l}\text { Sesuai } \\
\text { Harapan }\end{array}$ & Valid \\
\hline$\overline{2}$ & $\begin{array}{l}\text { Mengisi data pada search } \\
\text { engine }\end{array}$ & Search: Kaos & $\begin{array}{l}\text { Sistem menerima data } \\
\text { yang diberikan dan } \\
\text { langsung memproses } \\
\text { data tersebut }\end{array}$ & $\begin{array}{l}\text { Sesuai } \\
\text { Harapan }\end{array}$ & Valid \\
\hline 3 & $\begin{array}{l}\text { Mengisi salah satu } \\
\text { datayang salah dan } \\
\text { langsung mengklik } \\
\text { tombol "PROCESS } \\
\text { CHECKOUT" }\end{array}$ & Nama: (Kosong) & $\begin{array}{l}\text { Sistem tidak } \\
\text { menerima akses } \\
\text { untuk checkout dan } \\
\text { menunjukkan "invalid } \\
\text { nama" }\end{array}$ & $\begin{array}{l}\text { Sesuai } \\
\text { Harapan }\end{array}$ & Valid \\
\hline$\overline{4}$ & $\begin{array}{l}\text { Mengisi salah satu } \\
\text { datayang salah dan } \\
\text { langsung mengklik } \\
\text { tombol "PROCESS } \\
\text { CHECKOUT" }\end{array}$ & $\begin{array}{l}\text { Nama: LeopardEmail } \\
\text { (Kosong) }\end{array}$ & $\begin{array}{l}\text { Sistem tidak } \\
\text { menerima akses } \\
\text { untuk checkout dan } \\
\text { menunjukkan "email" }\end{array}$ & $\begin{array}{l}\text { Sesuai } \\
\text { Harapan }\end{array}$ & Valid \\
\hline 5 & $\begin{array}{l}\text { Mengisi salah satu } \\
\text { datayang salah dan } \\
\text { langsung mengklik } \\
\text { tombol "PROCESS } \\
\text { CHECKOUT" }\end{array}$ & $\begin{array}{l}\text { Nama: Leopard Email: } \\
\frac{\mathrm{K}^{* * * \star} @ \text { gmail.com }}{\mathrm{HP}:(\text { Kosong) }}\end{array}$ & $\begin{array}{l}\text { Sistem tidak } \\
\text { menerima akses } \\
\text { untuk checkout dan } \\
\text { menunjukkan "invalid } \\
\text { phone" }\end{array}$ & $\begin{array}{l}\text { Sesuai } \\
\text { Harapan }\end{array}$ & Valid \\
\hline 6 & $\begin{array}{l}\text { Mengisi salah satu } \\
\text { datayang salah dan } \\
\text { langsung mengklik } \\
\text { tombol "PROCESS } \\
\text { CHECKOUT" }\end{array}$ & $\begin{array}{l}\text { Nama: Leopard Email: } \\
\mathrm{k}^{\star * \star \star} @ \text { gmail.com } \\
\text { HP: } 08138039^{\star \star \star \star} \\
\text { Alamat: (Kosong) }\end{array}$ & $\begin{array}{l}\text { Sistem tidak } \\
\text { menerima akses } \\
\text { untuk checkout dan } \\
\text { menunjukkan "invalid } \\
\text { address" }\end{array}$ & $\begin{array}{l}\text { Sesuai } \\
\text { Harapan }\end{array}$ & Valid \\
\hline$\overline{7}$ & $\begin{array}{l}\text { Mengisi salah satu } \\
\text { datayang salah dan } \\
\text { langsung mengklik } \\
\text { tombol "PROCESS } \\
\text { CHECKOUT" }\end{array}$ & $\begin{array}{l}\text { Nama: Leopard Email: } \\
\mathrm{k}^{\star \star \star \star} @ \text { gmail.com } \\
\text { HP: } 08138039^{\star \star \star \star *} \\
\text { Alamat: Jl. KP Jawa Pilih } \\
\text { Pengiriman: } \\
\text { (Kosong) }\end{array}$ & $\begin{array}{l}\text { Sistem tidak } \\
\text { menerima akses } \\
\text { untuk checkout dan } \\
\text { menunjukkan "invalid } \\
\text { Shipping" }\end{array}$ & $\begin{array}{l}\text { Sesuai } \\
\text { Harapan }\end{array}$ & Valid \\
\hline$\overline{8}$ & $\begin{array}{l}\text { Mengisi salah satu } \\
\text { datayang salah dan } \\
\text { langsung mengklik } \\
\text { tombol "PROCESS } \\
\text { CHECKOUT" }\end{array}$ & $\begin{array}{l}\text { Nama: Leopard Email: } \\
\mathrm{k}^{\star \star \star \star} @ \text { gmail.com } \\
\mathrm{HP}: 08138039^{\star \star \star \star} \\
\text { Alamat: JI. KP Jawa Pilih } \\
\text { Pengiriman: COD } \\
\text { Tanggal Pengiriman: } \\
\text { (kosong) }\end{array}$ & $\begin{array}{l}\text { Sistem tidak } \\
\text { menerima akses untuk } \\
\text { checkout dan } \\
\text { menunjukkan "invalid } \\
\text { dateshipping" }\end{array}$ & $\begin{array}{l}\text { Sesuai } \\
\text { Harapan }\end{array}$ & Valid \\
\hline
\end{tabular}

\section{Kesimpulan}

Analisis dari aplikasi startup yang dilakukan, diperoleh kesimpulan sebagai berikut. Pertama, Aplikasi ini diharapkan dapat menjadi solusi bagi penjual untuk fokus pada penjualan produk distro secara online dimasa pandemi. Kedua, Menyebarluaskan aplikasi Distro supaya lebih dikenal luas oleh masyarakat, sehingga berminat untuk menggunakan aplikasi Distro. Perancangan aplikasi ini pasti menghadapi berbagai hambatan dan ketidak sempurnaan dalam pelaksanaannya. Perancangan aplikasi ini bisa berubah seiringnya waktu. Untuk melengkapi perancangan aplikasi ini, dengan mencari sponsorship atau partnership yang cocok dan ideal.

\section{Referensi}

[1] M. Andy Zaki, I. Nuzar, W. E. Saputro, B. D. S. Prayusta, S. B. Wijaya and M. Riswan, "Mapping dan Database Startup," MIKTI dan Teknopreneur Indonesia, 2018.

[2] T. Taufik and E. A. Ayuningtyas, "Dampak Pandemi Covid 19 Terhadap Bisnis Dan Eksistensi Platform Online," J. Pengemb. Wiraswasta, vol. 22, no. 01, p. 21, 2020, doi: 10.33370/jpw.v22i01.389. 
[3] E. Budiyanti, "Dampak Virus Corona Terhadap Sektor Perdagangan Dan Pariwisata Indonesia," Kaji. Bid. Ekon. Dan Kebijak. Publik, vol. XII, no. 4, pp. 19-24, 2020.

[4] A. Tarina, "Urgensi izin usaha dalam perdagangan melalui sistem elektronik bagi usaha mikro dan kecil," J. Pelita Ilmu, vol. 14, no. 2, pp. 88-106, 2020.

[5] A. Fauzi and E. Harli, "Rancang Bangun Sistem Informasi Akademik Smk Negeri 1 Depok Berbasis Android Dengan Pendekatan Rapid Application Development," J. Tek. Inform., vol. 12, no. 2, pp. 129-136, 2019, doi: 10.15408/jti.v12i2.10939.

[6] E. Pudjiarti, A. A. Yana, and N. Hidayatun, "Pembangunan e-Commerce Berbasis Web untuk Strategi Penjualan CCTV," Jurnal Sistem Informasi STMIK Antar Bangsa, vol.8 no. 1, pp. 42-45, 2019.

[7] T. S. Jaya, "Pengujian Aplikasi dengan Metode Blackbox Testing Boundary Value Analysis (Studi Kasus: Kantor Digital Politeknik Negeri Lampung)," J. Inform. Pengemb. IT, vol. 3, no. 2, pp. 45-46, 2018, doi: 10.30591/jpit.v3i1.647.

[8] A. Rossidah, A. K. Hidayah, S. Fernandez, and A. Sonita, "Pengembangan Aplikasi Monitoring Hasil Belajar Santri Berbasis Android (Study Kasus Rumah Tahfidz Bakti llaahi Bengkulu)," J. Innov., vol. 2, pp. 10-15, 2021.

[9] N. M. Rahman, "Analisis Perancangan Sistem Informasi Pada Pembuatan Aplikasi Deaf Care Dengan Menggunakan Metode Waterfall Dan Black Box Testing," Universitas Islam Indonesia, 2020.

[10] H. Hasugian and A. N. Shidiq, "Rancang Bangun Sistem Informasi Industri Kreatif Bidang Penyewaan Sarana Olahraga," Semin. Nas. Teknol. Inf. dan Komun. Terap. 2012, vol. 2012, no. Semantik 2012, pp. 606-612, 2012.

[11] E. Susena and T. Budi Santoso, "Sistem Penjualan Online Berbasis Website: Studi Kasus di Infomedia Komputer," J. Elektron. List. dan Teknol. Inf. Terap., vol. 1, no. 1, pp. 38-44, 2019.

[12] M. Iyansyah, S. Sari, S. Shaddiq, and H. . Zainul, "Literasi Manajemen Komunikasi Pemasaran Dalam Melaksanakan Etika Dan Standar Periklanan," Jurnal Revolusi Indonesia, vol. 1, no. 10, pp. 1073-1091, 2021.

[13] E. Budihartono, P. Harapan, B. Tegal, and S. Altimeter, "Monitoring Ketinggian Plateau Berbasis Mikrokontroler Menggunakan Atmega 328 dan Sensor Altimeter," Jurnal Sebatik, vol. 23, no.2, pp. 440-446, 2019.

[14] C. Vikasari, P, "Sistem Informasi Manajemen Pada Jasa Expedisi Pengiriman Barang Berbasis Web 1," Jurnal Teknik Informatika dan Sistem Informasi (JATISI), vol. 4, no. 2, pp. 123-132, 2018.

[15] W. Dari and L. I. Prahartiwi, "Sistem Informasi Penjualan Alat Musik Menggunakan Model Water Fall," Jurnal Khatulistiwa Informatika, vol. 6, no. 1, pp. 87-96, 2018.

[16] M. K. Hidayat, R. Catur, and P. Ningrum, "Sistem Informasi Penjualan Online Pada Toko Yusuf Bekasi," Indonesian Journal on Computer and Information Technology (IJCIT), vol. 2, no. 2, pp. 24-30, 2017.

[17] M. Septiani and S. J. Kuryanti, "Sistem Pakar untuk Mendiagnosa Penyakit Saluran Pernapasan pada Anak," Sinkron: Jurnal dan Penelitian Teknik Informatika, vol. 2, no. 2, pp. 23-27, 2018.

[18] H. F. Siregar and Y. H. Siregar, "Perancangan Aplikasi Komik Hadist Berbasis Multimedia," Jurnal Teknologi Informasi (Jurti), vol. 2, no. 2, pp. 113-121, 2018.

[19] O. Irnawati, "Implementasi Metode Waterfall Pada Sistem Informasi Stock Opname," Indonesian Journal on Software Engineering (IJSE), vol. 4, no. 1, pp. 79-84, 2018.

[20] E. Prasetyo, "Aplikasi Pengarsipan Surat Pada Kantor Kepala Desa Tanjung Kerang," Jurnal Teknologi Informasi dan Komunkasi Politeknik Sekayu (TIPS), vol. 10, no. 2, pp. 11-17, 2020.

[21] T. R. Mujiyanto, "Aplikasi Pusat Pertukaran Data Pada Sistem Peradilan Pidana Terpadu Berbasis Teknologi Informasi (SPPT-TI)," JISAMAR (Journal of Information System, Applied, Management, Accounting and Research), vol. 5, no. 2, 2021, doi: 10.52362/jisamar.v5i2.

[22] N. Hadinata, "Implementasi Metode Multi Attribute Utility Theory (MAUT) Pada Sistem Pendukung Keputusan dalam Menentukan Penerima Kredit," Jurnal Sisfokom, vol. 7, no. 2, pp. 87-92, 2018. 
[23] E. P. Sari, E. Pudjiarti, and H. Susanti, "Sistem Informasi Penjualan Pakaian Wanita Berbasis Web (E- Commerce ) Pada Pt . Bunitop Indonesia," Jurnal Teknologi Informasi Mura Juni, vol. 12, no. 01, pp. 1-13, 2020.

[24] E. Pudjiarti, D. Nurlaela, and W. Sulistyani, "Sistem Informasi Penjualan Beras Berbasis Website," Indones. J. Softw. Eng., vol. 5, no. 1, pp. 62-74, 2019, doi: 10.31294/ijse.v5i1.5865.

[25] M. S. Mustaqbal, R. F. Firdaus, and H. Rahmadi, "Pengujian Aplikasi Menggunakan Black Box Testing Boundary Value Analysis (Studi Kasus: Aplikasi Prediksi Kelulusan SNMPTN)," Jurnal IImiah Teknologi Informasi Terapan (JITTER), vol. I, no. 3, p. 34, 2015. 